\title{
The Contribution of French Musicians wILLIAM to the Genesis of the BOWEN Italian Madrigal
}

Résumé : Comment se fait-il qu'un Français soit considéré comme le fondateur du madrigal, un des artefacts caractéristiques de la culture italienne de la Renaissance? Pour répondre à cette question, il faut commencer par un bref survol des commentaires et des documents d'archives de la Renaissance qui insistent sur le fait que les musiciens français et franco-flamands prédominaient dans les chapelles italiennes des $X V^{e}$ et $X V I^{e}$ siècles, en raison de politiques culturelles délibérées. Dans une réflexion plus précise sur la genèse du madrigal à Florence, cet article examine le fonctionnement interne des chapelles florentines au début du XVI siècle et, plus particulièrement, le rôle du Français Philippe Verdelot, le maître de chapelle de la Cathédrale et du Baptistère dans les années 1520. Celui-ci fut impliqué de près dans le développement du madrigal à ses tout débuts.

$\mathrm{H}^{\mathrm{ow}}$ is it that a Frenchman came to be a father of the Italian madrigal? According to modern musicologists, Phillipe Verdelot, a composer born in northern France circa 1480-85, was an influential pioneer in a genre which is intimately associated with the very heart of the Italian Renaissance. ${ }^{1}$ Yet for those unfamiliar with the history of European music in the fifteenth and sixteenth centuries, it seems counter-intuitive to attribute a substantial role to a foreigner in the creation of one of the musical genres which defined Italian Renaissance music and played a significant part in a burgeoning Italian cultural nationalism. Thus it is very much to the point in the context of this collection of essays to consider what the case of the madrigal tells us about cultural leadership and cultural exchange in the Renaissance. My answer begins by looking at what the critics of the time have to say about the pre-eminent musicians in the fifteenth and sixteenth 
centuries. This leads to a sketch of trends pertaining to the presence of foreign composers and their music in Italy. ${ }^{2}$ Within this framework, I will shift from consideration of the musical establishment to the genesis of the madrigal itself in Florence during the 1520s.

From descriptions of the musical life of the time, it seems that musicians and their patrons generally recognized the cultural dominance of northern Europe, specifically northern France and the Low Countries, during the fifteenth century. Consider, for example, the commentary of Johannes Tinctoris (c. 1435-1511), a composer and theorist from the North, who wrote a number of treatises on music during the 1470s while he was in Naples in the service of King Ferrante I. ${ }^{3}$ In his Proportionale musices (1472-73), Tinctoris divides the history of Western music into three broad periods: a remote or ancient past, a more recent past beginning with Christ and reaching to the fourteenth century, and the modern era. Tinctoris then goes on to describe the birth of a new art in the early fifteenth century, which reached its perfection in the music of his generation. In the same treatise, he writes:

At this time, consequently, the possibilities of our music have been so marvelously increased that there appears to be a new art, if I may so call it, whose fount and origin is held to be among the English, of whom Dunstable stood forth as chief. Contemporary with him in France were Dufay and Binchois, to whom directly succeeded the moderns Ockeghem, Busnois, Regis, and Caron, who are the most excellent of all the composers I have ever heard. Nor can the English, who are popularly said to shout while the French sing, stand comparison with them. For the French contrive music in the newest manner for the new times, while the English continue to use one and same style of composition, which shows a wretched poverty of invention. ${ }^{4}$

Here Tinctoris identifies two groups of composers. The first are selected from the generation born in the last decade of the fourteenth century, including John Dunstable (c. 1390-1453), Guillaume Du Fay (c. 1397-1474), and Gilles Binchois (c. 1400-60). ${ }^{5}$ For the moderns, that is, composers still active at the time he was writing the treatise, Tinctoris names Johannes Ockeghem (c. 1410-97) with others born some time later, that is, Antoine Busnoys (c. 1430-92), Johannes Regis (c. 1425-c. 1496), and Firminus Caron (fl. 1460-75). ${ }^{6}$

That Tinctoris identifies all but Dunstable as French provides an opportune moment to pause briefly to reflect on the matter of nationality. It is reasonable to assume that Tinctoris was sensitive to the issues of cultural and political identity in the Low Countries, in so far as he himself was from Braine-l'Alleud, a town in the Flemish area surrounding the French-speaking city of Brussels. Thus it is interesting that, whether by choice or from ignorance of specific details, Tinctoris glosses over Dufay's Flemish roots 
and, more generally, the fact that through their birth and their careers, the composers he names are as a group primarily tied to Artois, Brabant, Flanders, and Hainault, that is, lands acquired by the Dukes of Burgundy. What we might learn from this is that Tinctoris assimiliates regional differences under a broad reading of France and what is French. Though musicologists today continue to struggle with the inherent ambiguities and how best to characterize the nationality of these composers, ${ }^{7}$ for the purposes of this essay I am inclined to follow Tinctoris. Accordingly, I will be inclusive, allowing that the extremely rich musical culture of the musicians from the Netherlands is directly related to "French" music and its impact on the rest of Europe. ${ }^{8}$ Further, I will adopt the current practice among musicologists by referring to composers from this area as "Franco-Flemish." 9

While I do not intend to explore what Tinctoris specifically has in mind when he talks about this new art, ${ }^{10}$ it is worth noting that he sees a clear progression from a new art created by English composers, which is then taken up by their contemporary and succeeding composers in France and northern Europe: according to Tinctoris, the English in the meantime seem to lose their way. That Tinctoris felt strongly about the importance of the new art is clear from a statement in a later treatise, the Liber de arte contrapuncti of 1477: "Further, although it seems beyond belief, there does not exist a single piece of music, not composed within the last forty years, that is regarded by the learned as worth hearing." 11 To avoid confusion, I should explain that "composed" music here refers to polyphony (that is, music in which two or more lines or melodies sound simultaneously) and add that this statement does not constitute a rejection of the monophonic chant which Tinctoris assumes in his description of music of the church. It does mean, however, that Tinctoris had no use for any earlier composed music.

My point in introducing this account is quite simple. Music critics of the Renaissance tend to see their polyphonic art as something that was born in the North and then nurtured primarily by composers from northern France and the Low Countries. ${ }^{12}$ Tinctoris mentions two generations. As Jessie Ann Owens observes in her article on the definition of the Renaissance, these generations and each of the following generations extol the superiority of their art and celebrate their own heroes. ${ }^{13}$ Although Owens' study is directed at different questions and the documentation is not exhaustive, what she has compiled and her analysis of it suggest that the perception of the superiority of northern composers is persistent and widespread during the fifteenth century and that it continues beyond the generation of Josquin des Prez, an exceptionally well-known French composer, who had an active career in Italy and France until his death in $1521 .{ }^{14}$ Sources dating from the second half of the sixteenth century certainly do recognize new superstars in the 
post-Josquin era; particular mention is made of Adrian Willaert ( $c$. 1490-1562) and Cipriano de Rore (1515/16-1565), both from Flanders and both prominent figures in Italy. ${ }^{15}$ However, these same sources increasingly name Swiss, German, Italian, and Spanish composers, in addition to those from France and the Low Countries, thereby suggesting that the absolute hegemony of the North was seen to erode slowly, beginning around the time that the madrigal was born. ${ }^{16}$

Given that contemporary critics present French and Franco-Flemish composers as the dominant musical force during the fifteenth century and through most of the sixteenth century, it is not surprising that foreigners had a significant impact on musical life in Italy. Indeed, according to Claude Palisca,

During the fifteenth and early sixteenth centuries music in Italy spoke a different
language from that of the other arts. The painters, sculptors, architects, poets, and
other writers were indigenous Italians. But in the ducal and papal chapels
professional choirs made up almost wholly of singers trained in places like
Cambrai, Bruges, or Antwerp sang music by Guillaume Dufay, Antoine Busnois,
Jacob Obrecht, Johannes Ghiselin, Johannes Ockeghem, and Jean Mouton, all of
whom made short visits to Italy but whose principal employment lay across the
Alps. Others, like Josquin des Prez in Milan and Rome, Heinrich Isaac in
Florence, Philippe Verdelot and Jacques Arcadelt in Florence, Adrian Willaert
in Ferrara and Venice, and Jacquet (Colebault) of Mantua in Ferrara pursued the
major part of their careers in Italian cities. ${ }^{17}$

Though Palisca's generalization shows a certain rhetorical flair, it also discloses a fundamental trend which bears further investigation, at least with regard to music. (I will set aside his characterization of the other arts for those more qualified.) Of the musicians listed by Palisca, all are northerners of French or Franco-Flemish descent. ${ }^{18}$ Before testing the validity of Palisca's claim that Italian chapels were thoroughly dominated by French and Franco-Flemish singers and composers, let me first forestall any concerns about its relevance by explaining the connection between professional chapel musicians and the creators of the Italian madrigal.

The short answer is that they are the same people. ${ }^{19}$ Through their training in choir and collegiate schools, they were able to read, write, and perform polyphonic music. Accordingly, graduates of this system might find musical careers at least as singers, if not as composers, of sacred music. But such careers commonly required some participation in the performance and composition of polyphonic settings of secular poetry outside the church or courtly chapel. Here, in the world of secular entertainment, their contribution overlaps with that of the minstrels - musicians trained outside the church through apprenticeships, who were not necessarily able to read or write music. Nonetheless, it is the extension of the church-based musicians into 
the secular realm which is the immediate context for the genesis of the Italian madrigal. With this in mind, let us now return to the matter of French and Franco-Flemish musicians in Italy.

There is ample documentary evidence that Italian patrons actively sought to obtain the services of the most talented chapel singers, that is, essentially, singers trained in the North. Perhaps the most spectacular and well-documented campaign in the late fifteenth century is that of the Milanese court of the 1470s, where Galeazzo Maria Sforza showed an almost ruthless determination to build a musical establishment which would surpass anything found in Italy and challenge the best Europe had to offer. ${ }^{20}$ Raiding singers not only from local chapels and neighbouring cities, but also from Rome, Naples, Savoy, France, Flanders, and Burgundy, Galeazzo achieved his goal by using the international networks of patrons, senior members of the church, diplomats, and, indeed, singers, who acted as his talent scouts. Enticing singers with substantial financial inducements, Galeazzo created an exceptionally large musical organization with two professional choirs numbering forty adult singers in $1474 .{ }^{21}$

That Galeazzo instigated diplomatic squabbles in the process of creating his choirs is but a further indication of the scale and importance of the enterprise. Indeed, while it is worth noting that Galeazzo likely had a predilection for French music, ${ }^{22}$ which was fairly common in well-educated society in Italy, such a display of cultural leadership was a significant reflection of the grandeur and vision of the patron. At this level, music and the patronage system could be used to demonstrate cultural and political alignment. Lewis Lockwood suggests as much in his study of French music and musicians in Ferrara during the early decades of the sixteenth century. He concludes that there was

an international patronage system that made possible the wide transmission of music along a distant network. The network was wide yet by no means universal. To enter it, a small court like that of Ferrara, which could never match its great rivals in power and wealth, had to adopt the patronage of music and musicians as virtually a prime matter of cultural policy; the regime had to possess the means and the willingness to acquire the musical talent, to use the diplomatic channels, and to maintain the commitment, that made possible its participation in the system. That in fact such a policy was not only at work at this time, but was the continuation of a long-standing pro-French cultural position, is indeed demonstrable. ${ }^{23}$

In sum, Palisca is right: recruiting northerners to Italian chapels was a serious business intended not only to satisfy personal taste but also to serve a cultural and political agenda.

The studies by Allan Atlas of the Neapolitan royal chapel provide an interesting confirmation of this point. ${ }^{24}$ Under Alfonso V of Aragon, the 
roster of musicians was very much dominated by Spaniards. But this started to change at the end of Alfonso's reign, and the change accelerated in the 1460s and 1470s under Ferrante I with the selection of northern singers. The weakening of the Spanish influence and the shift toward a more typically Italianate model, that is, with a preponderance of northern musicians, reflect a shift in the political reality for Ferrante, who was somewhat isolated from Spain because of the division of the Aragonese realm. The shift also reveals a move from the cultural provincialism of Alfonso to the use by Ferrante of musical patronage for political ends. As Atlas puts it,

His [Ferrante's] was a strategy that fitted happily with a new attitude towards music and musical institutions that developed throughout Italy during the last third of the century: one in which the court chapel became an ever more important symbol of the cultural status of the state and one that led such courts as Naples, Milan, Ferrara, Florence and the papacy to compete intensely with one another for the services of the most renowned Franco-Netherlandish composers and singers, who had by now come to dominate the field of polyphonic music. ${ }^{25}$

Nonetheless, given the ambiguities in the extant financial and legal records, it is hard to quantify with any precision the influx into Italy of northern singers and composers.

It seems fair, however, to estimate from the available evidence that the majority of Galeazzo's forty professional musicians in 1474 were French and Franco-Flemish. Even more striking is that the only well-known composers in the group are from northern France and the Netherlands. Moreover, three additional composers, all French, are named in documents dating from 1476-77, showing not only an unusually high number of first-rate composers, but also a total domination of the chapels by French music. ${ }^{26}$ Roughly comparable results are found in other archival research. Lewis Lockwood, for example, has shown that the Ferrarese court chapel of Ercole I d'Este had more or less equal numbers of northern and native Italian singers; consistently, the largest group of foreign singers was French, followed by the Franco-Flemish. ${ }^{27}$ Christopher Reynolds' study of musicians at St. Peter's in Rome paints a slightly more complex picture, in so far as the ratio of foreigners to Italian musicians shifts during the second half of the fifteenth century and into the sixteenth century, according to the dictates of the individual popes. Yet it appears that foreigners, primarily French and Franco-Flemish musicians, may have had a slight majority over the period and that they commonly received better wages. ${ }^{28}$ In sum, such archival research refines Palisca's broad generalization with quantitative evidence indicating an impressive presence of foreign singers and composers. 
Yet there is an intractable problem here, in that Palisca's characterization of the complete dependency of Italian musical establishments on northerners cannot be reduced simply to measuring numbers of French and Franco-Flemish musicians in Italian chapels. The aggressiveness of the recruiting campaigns, the high wages given to northerners, and the seniority accorded them give tangential evidence of a qualitative difference, which resonates with Tinctoris' assessment of their importance. Moreover, this view finds additional support in what music was printed. It is worth noting that French chansons constitute the majority of the compositions in the first printed book of polyphonic music, the Harmonice musices Odhecaton, produced by Ottaviano Petrucci in Venice in 1501 as the first of three similar volumes. That Petrucci's chansonniers successfully launched a printing industry may be taken as a significant sign of the market and its preferences. Accordingly, though Palisca's remarks may seem charged by rhetorical excess, there are a variety of indicators which support his view that "music in Italy spoke a different language." 29

Tinctoris' assessment of the importance of French composers, coupled with Palisca's view of the Italian music scene, answers my opening question How is it that a Frenchman came to be a father of the Italian madrigal? in part. For I have shown that French and Franco-Flemish singers and composers were not only perceived to be leaders, but also welcomed as a dominating presence in Italy before and during the time when the madrigal was conceived. Accordingly, it is reasonable that a French composer should have been a central figure in the creation of this new genre of Italian polyphonic music. It remains to consider how the specific evidence for musical life in Florence and the appearance of the madrigal itself fit the more general picture.

Following the pattern of other Italian cities, Florence enjoyed the build-up of its musical chapels in the latter half of the fifteenth century, though, in this case, the centre of activity for polyphonic music was not the Medici court itself but the chapels of the Cathedral of Santa Maria del Fiore, the Baptistery of San Giovanni, and the convent church of Santissima Annunziata. ${ }^{30}$ The growth of the chapel choirs accelerated greatly, beginning in the 1480s, under the powerful influence of Lorenzo de' Medici, ${ }^{31}$ thereby attracting such notable northern composers as Alexander Agricola, Johannes Ghiselin, and Heinrich Isaac. ${ }^{32}$ However, the grow th withered with the death of Lorenzo in 1492, the inept handling of diplomatic relations with France by his successor, Piero de' Medici, which led quickly to the expulsion of the Medici in 1494, and the ensuing years under the reforming influence of Girolamo Savonarola. ${ }^{33}$ Constrained by financial difficulties, the renewal of the chapel choirs in Republican Florence was slow. However, with their 
restoration in 1512, the Medici encouraged the expansion and improvement of the standards of the musical chapels, in part through the recruitment of northern composers and singers. ${ }^{34}$ Thus, by the time that Verdelot arrived in Florence in 1521, the chapels had reclaimed their position in Florentine life, though not with the splendour experienced during the last years of the Laurentian period. ${ }^{35}$

Where Verdelot lived and worked before his appearance in Florence is still a matter for speculation. Born around 1480-85 in Verdelot, Les Loges, Seine-et-Marne, it is assumed that he spent his early career in northern France before moving to Italy. Although there is evidence linking him to Venice and Rome at various points in the period from 1510 to 1520 , we are not on solid ground until May 1521, when he is known to have been in Florence, quite likely in the service of Cardinal Giulio de' Medici. ${ }^{36}$ Within a few years he had become a leading figure in Florence's musical life with appointments as maestro di cappella at the Cathedral and Baptistery. Aside from a well-known trip to Rome (December 1523 to January 1524) at the request of Giulio de' Medici to celebrate his elevation to the papacy, it seems that Verdelot was based in Florence until 1527, when the chapel was dissolved on account of the plague. Whether Verdelot himself survived the plague is not certain. ${ }^{37}$

In spite of the lack of detail in the account of Verdelot's life, we are nonetheless secure in placing him in Florence during the first stage of the madrigal's creation, that is, during the 1520s: based on the extant evidence, it is possible that Verdelot's earliest madrigals were written just before his arrival in Florence, possibly in Rome or Venice. Further, Verdelot was recognized as a superior musician, not only through his appointments in the most prestigious musical establishments, but also through various references to him in letters and treatises. ${ }^{38}$ More significantly for our purposes, Verdelot is tied to the genesis of the madrigal itself through his dominating presence in the early manuscripts which circulated in the $1520 \mathrm{~s} .{ }^{39}$ And he is given pride of place in printed books, where his contribution is first signalled in prints of individual madrigals dating from as early as 1520; then by his eight madrigals, which outnumber those of all other composers in the first collection to bear the title "madrigal," the Madrigali de diversi musici libro primo de la Serena (Rome, 1530); and finally by entire books dedicated to his madrigals, which appear beginning with his Il primo libro de madrigali (Venice, 1533), followed by reprints to satisfy popular demand until the 1560 s.

Although this substantiates Verdelot's role as a father of the madrigal, it begs the question of how he became involved in the development of a new genre. Part of the answer may lie in cultural links between Medicean Rome 
and Florence. It is plausible that Verdelot, along with lesser-known pioneers of his generation, through their connections to the two cities were inspired by the presence of Pietro Bembo and the Petrarchists in Rome (1513-21) to make a conscious effort to create an Italian music appropriate to the new ideals for reading poetry. 40 This speculation assumes to a certain extent the active interest and support of local patrons and brings us to a curious irony in the connection of Verdelot to the early madrigal. Though Verdelot was likely supported initially by Giulio de' Medici and thereafter thrived in the chapels influenced by the Medici, he had pro-Republican leanings. Apparently, along with his meteoric rise in the chapels, Verdelot made a name for himself in Florentine intellectual and social circles. Indeed, it is surmised that he may have participated in gatherings at the Orti Oricellari, though perhaps not in the anti-Medicean plots. Nonetheless, Verdelot knew Machiavelli, setting a number of his madrigal texts to music, and there are signs of pro-Republican sympathies in a few of his motet texts. ${ }^{41}$ Thus it would seem that the early growth of the madrigal was nourished not so much by the Medici as by other prominent Florentine families, such as the Strozzi, who are associated with the extant manuscripts. ${ }^{42}$

Thus, in answer to our opening question as to how a Frenchman could come to be a father of the Italian madrigal, Verdelot's role follows a general pattern in the musical culture of Italy in the late fifteenth and early sixteenth centuries. It is fitting, in the context of this collection of essays, to make a final observation. The French or Franco-Flemish influence on the madrigal reaches beyond the matter of the nationality of the composer. For although the issue is fraught with unresolved complexities, research over the past few decades indicates that Verdelot developed the musical style of the early madrigal through a synthesis of the styles with which he was most familiar and which were most adaptable to the aesthetic of the new genre. Thus he looked quite naturally not to the Italian frottola, a simple form cultivated in northern Italy, but to the French or Franco-Flemish motet and the French chanson. ${ }^{43}$ Accordingly, we have a case of cultural appropriation, wherein a French composer, working in Italy for Italian patrons and using musical models developed in northern Europe, made a critical contribution to the genesis of a new genre, which was soon identified with the heart of the Italian Renaissance.

Victoria College, University of Toronto 


\section{Notes}

1. This assessment of Verdelot is commonly reported in recent music texts and dictionaries: see, for example, Allan W. Atlas, who writes, "Given this 'Italianness,' it is ironic that the early madrigal developed mainly at the hands of French and Flemish composers," and then goes on to name Verdelot in Renaissance Music: Music in Western Europe, 1400-1600 (New York: Norton, 1998), p. 428; Leeman L. Perkins, who describes Verdelot as "a key figure in the development of the new madrigal" in Music in the Age of the Renaissance (New York: Norton, 1999), p. 659; and H. Colin Slim and Stefano La Via, who summarize Verdelot's achievement by calling him "the most important composer of Italian madrigals before Arcadelt, and one of the pioneers of the genre" in their entry on Verdelot in Grove Music Online, ed. L. Macy, http://www.grovemusic.com. It is noteworthy that Arcadelt was also a foreigner, probably from northern Europe.

2. Unfortunately, I have been unable to locate a copy of Nicoletta Guidobaldi, ed., Regards croisés. Musiques, musiciens, artistes et voyageurs entre France et Italie au $\mathrm{XV} e$ siècle (Paris: Minerve, 2002), which is relevant to this discussion.

3. Though the details of Tinctoris's life are sketchy, it appears that he was born in Brainel'Alleud, near Nivelles. After working in Orléans and Chartres, he was employed in Naples from the early 1470 s to the early 1490 s. There are indications that he subsequently travelled to Rome, Buda, and Naples, and then may have returned to his homeland. See Ronald Woodley, "Johannes Tinctoris: A Review of the Documentary Biographical Evidence," Journal of the American Musicological Society 34 (1981): 217-48.

4. From Oliver Strunk's translation first published in 1950 and now reissued in The Renaissance, ed. Gary Tomlinson, vol. 3 of Source Readings in Music History, ed. Oliver Strunk, rev. ed. Leo Treitler (New York: Norton, 1998), pp. 14-15. Original: "Quo fit ut hac tempestate facultas nostrae musices tam mirabile susceperit incrementum quod ars nova esse videatur, cuius, ut ita dicam, novae artis fons et origo apud Anglicos quorum caput Dunstaple exstitit, fuisse perhibetur, et huic contemporanei fuerunt in Gallia Dufay et Binchois, quibus immediate successerunt moderni Okeghem, Busnois, Regis et Caron, omnium quos audiverim in compositione praestantissimi. Haec eis Anglici nunc, licet vulgariter iubilare, Gallici vero cantare dicantur, veniunt conferendi, illi etenim in dies novos cantus novissimae inveniunt, ac isti, quod miserrimi signum est ingenii, una semper et eadem compositione utuntur" (Johannis Tinctoris Opera Theoretica, ed. Albert Seay, Corpus Scriptorum de Musica, 22 [(n.p.): American Institute of Musicology, 1975-78], vol. 2a: 10). Seay describes the seven manuscript sources of the treatise and the treatise itself in vol. 1: 10-13 and 21-25.

5. For a full-length study of Dunstable (or Dunstaple), see Margaret Bent, Dunstaple (London: Oxford University Press, 1981). According to the latest research, Du Fay was born in Flemish-speaking Beersel near Brussels, was a chorister at Cambrai Cathedral, and returned periodically to Cambrai during his years abroad: David Fallows' Dufay, rev. ed. (London: Dent, 1987), should be read with Alejandro Enrique Planchart, "The Early Career of Guillaume Du Fay," Journal of the American Musicological Society 46 (1993): 341-68; Barbara Haggh, "Guillaume Du Fay's Birthplace: Some Notes on a Hypothesis," Revue Belge de Musicologie 51 (1997): 17-21; and Alejandro Enrique Planchart, "Concerning Du Fay's Birthplace," Revue Belge de Musicologie 54 (2000): 225-30. Gilles Binchois was likely born in Mons and spent most of his life in Flanders, in sharp contrast to Du Fay, who travelled extensively and worked many years in Italy. There is no full study of Binchois: for a review of the literature, see David Fallows, "Binchois," in Grove Music Online. 
6. Ockeghem (or Okeghem) was born in Saint Ghislain, near Mons, and served in the French royal chapel for most of his life: see Martin Picker, Johannes Ockeghem and Jacob Obrecht: A Guide to Research (New York: Garland, 1988), as well as Leeman L. Perkins, "Ockeghem," in Grove Music Online. Though the birthplace of Busnoys is unknown, it is speculated that he was born in Busnes, a village near Béthune in northern France: see Paula Higgins, "Busnoys," in Grove Music Online. Documentary evidence locates him in Tours, Poitiers, and then in the Burgundian chapel. Although nothing is known about Regis's early life, there is solid documentary evidence that he worked at the church of St. Vincent, Soignies (north of Mons) from 1451 to the end of his life: see Sean Gallagher, "Regis," in Grove Music Online. Little is known about Caron. He may have been from Amiens: see David Fallows, "Caron," in Grove Music Online.

7. For example, Du Fay, who was born and raised in the Flemish-speaking town of Beersel, near Brussels, is variously described in recent publications as being either Flemish or French. See Christopher Reynolds, "Dufay, Guillaume," in Encyclopedia of the Renaissance, ed. Paul. F. Grendler (New York: Scribner's in assoc. with the Renaissance Society of America, 1999), 2: 221, where Du Fay is "Flemish," and Alejandro Enrique Planchart, "Du Fay, Guillaume," in Grove Music Online, where he is "French."

8. This is a fairly common approach explicitly recognized in Martin Picker, "Music in France," in Encyclopedia of the Renaissance, 4: 251-52.

9. Other terms have been used, including "Netherlandish" and "Franco-Netherlandish." Though "Burgundian" might seem appropriate because the area in question was ruled by the Dukes of Burgundy, the term has fallen out of use because of the need to avoid confusion with the duchy and county of Burgundy in the south: see Craig Wright and David Fallows, "Burgundy," in Grove Music Online.

10. In recent years, musicologists have re-examined Tinctoris's remarks on the new art, often challenging the apparent simplicity and historical validity of his message: see Reinhard Strohm, "The Humanist Idea of a Common Revival of the Arts and Its Implications for Music History," in Maciej Jablónski and Jan Steszewski, eds., Interdisciplinary Studies in Musicology: Report from the Third Interdisciplinary Conference (Poznán: Wydawn. Poznánskiego Towarzystwa Pryjaciól Nauk, 1997), pp. 7-25, and "Music, Humanism, and the Idea of a Rebirth of the Arts," in Reinhard Strohm and Bonnie J. Blackburn, eds., Music as Concept and Practice in the Late Middle Ages (Oxford: Oxford University Press, 2001), pp. 346-405; Rob C. Wegman on the commonly linked reference to La contenance angloise in Martin le Franc's poem Le champion des dames in "Johannes Tinctoris and the 'New Art'," Music and Letters 84.2 (2003): 171-88; and Ronald Woodley, "Renaissance Music Theory as Literature," Renaissance Studies 1 (1987): 209-20. The re-evaluation of Tinctoris does not affect my exegesis of the perception of national leadership.

11. The Renaissance: Source Readings in Music History, ed. and trans. Oliver Strunk (New York: Norton, 1965), vol. 3: 9. Original: "Neque quod satis admirari nequeo quippiam compositum nisi citra annos quadraginta extat quod auditu dignum ab eruditis existimetur" (Johannis Tinctoris Opera Theoretica, ed. Seay, 2: 12). Seay describes the three manuscript sources of this treatise in vol. 1: 10-13 and 20-21.

12. That is not to say that all critics approve the new art: see William R. Bowen, "Renaissance Perspectives on the (Re)birth of Music," forthcoming in Studi rinascimentali: Rivista internazionale di letteratura italiana 1.2 (2003), where I include the negative reaction of the late-sixteenth century writers Girolamo Mei and Vincenzo Galilei. Edward E. Lowinsky's classic article, "Music of the Renaissance as Viewed by Renaissance Musicians," 
revolves around this subject (The Renaissance Image of Man and the World, ed. Bernard O’Kelly [Columbus: Ohio State University Press, 1966], pp. 129-77).

13. Jessie Ann Owens, "Music Historiography and the Definition of the 'Renaissance'," Music Library Association Notes 47 (1990-91): 305-30, esp. 309-13 and Table 1, 320-21.

14. Investigation into Josquin's birthplace is ongoing. Since his family had connections to Condé and he was a choirboy at the cathedral in Saint-Quentin, it has been suggested that he may have been born in the environs of either city. His birthdate, normally given as around 1450 , is thought by some to be as late as 1455 . See Paul A. Merkley and Lora L. M. Merkley, Music and Patronage in the Sforza Court (Turnhout: Brepols, 1999), pp. 456-66, and Richard Sherr, "Chronology of Josquin's Life and Career," in The Josquin Companion, ed. R. Sherr (Oxford: Oxford University Press, 2000), ch. 2. The Merkleys' comments on the question of Josquin's nationality are particularly pertinent, in that they establish the complexity of determining nationality and, at the same time, raise the intriguing possibility that Josquin may have exploited the ambiguity (pp. 462-63).

15. Willaert was probably born in Bruges, but Roulaers is also cited as a possibility. Rore's birthplace was Ronse (Renaix), a small town west of Brussels. For the latest biographical information and bibliography, see Lewis Lockwood et al., "Willaert," and Jessie Ann Owens, "Rore," in Grove Music Online.

16. See Owens, "Music Historiography," pp. 320-21. Modern musicologists have fastened on this shift of leadership and commonly portray the late Renaissance as a period when major composers of international reputation are to be found in many countries. In a classic formulation of this view, Howard Mayer Brown defined music of the late sixteenth century by studying four masters: Giovanni Pierluigi da Palestrina (c. 1525-94) for Italy, Orlando di Lasso (1532-94) for the Netherlands, Tomás Luis de Victoria (c. 1548-1611) for Spain, and William Byrd (1543-1623) for England; see H. M. Brown and Louise K. Stein, Music in the Renaissance, 2nd ed. (Upper Saddle River, NJ: Prentice Hall, 1999), ch. 11. This formulation is retained by Leeman L. Perkins in his chapter on "The Final Synthesis," in Music in the Age of the Renaissance.

17. Claude V. Palisca, "Music in Renaissance Culture," Encyclopedia of the Renaissance, 4: 204.

18. Brief biographical information on Du Fay (Dufay), Busnoys (Busnois), Ockeghem, Josquin, Verdelot, and Willaert has already been given. Jacob Obrecht (1457/58-1505) was born in Ghent and worked primarily in Bergen op Zoom, Bruges, and Antwerp, though he spent many months in Ferrara: see Rob C. Wegman, Born for the Muses: The Life and Masses of Jacob Obrecht (Oxford: Clarendon Press, 1994), and "Obrecht, Jacob," in Grove Music Online. Johannes Ghiselin (fl. 1491-1507) is known primarily through his employment in Ferrara and Florence: see Clytus Gottwald, "Ghiselin, Johannes," in Grove Music Online. Jean Mouton (before 1459-1522) was likely born near Samer and spent much of his life working for the French court, a function which included travel to Italy: see Howard Mayer Brown and Thomas G. MacCracken, "Mouton, Jean," in Grove Music Online. Heinrich Isaac (c. 1450-1517) was born in either Flanders or Brabant and found patrons in the Medici and Maximilian I: see Reinhard Strohm and Emma Kempson, "Isaac, Henricus," in Grove Music Online. Jacques Arcadelt (c. 1507-68) likely arrived in Italy in the late 1520s, working in Florence and Rome before returning to France in 1551: see James Haar, "Arcadelt, Jacques," in Grove Music Online. Jacques Colebault (1483-1559), better known as Jacquet of Mantua, was born in Vitré and spent most of his life in Mantua: see George Nugent, "Jacquet of Mantua," in Grove Music Online. 
19. The pattern of musical training and careers in the Renaissance is ably summarized by Leeman L. Perkins in chapters 2 to 4 of Music in the Age of the Renaissance. The duties of chapel musicians and their convergence with secular music making are addressed in pp. 96-98. For more specialized information, see the studies of specific musical establishments cited in the subsequent notes.

20. The recruitment of singers and composers is detailed in William F. Prizer, "Music at the Court of the Sforza: The Birth and Death of a Musical Center," Musica Disciplina 43 (1989): 141-93, esp. 155-60, and Merkley and Merkley, esp. chapter 2. The Merkleys also provide extensive information on related financial matters in chapters 1 and 3.

21. The membership of Galeazzo's two choirs in 1474 is given in Merkley and Merkley, p. 102. The precise duties of the two groups are not known.

22. Prizer, pp. 150-55, reviews the documentary evidence of Galeazzo's musical education and tastes.

23. Lewis Lockwood, "Jean Mouton and Jean Michel: New Evidence on French Music and Musicians in Italy, 1505-1520," Journal of the American Musicological Society 32.2 (1979): 246.

24. Allan W. Atlas, Music at the Aragonese Court of Naples (Cambridge: Cambridge University Press, 1985), esp. pp. 30 and 38, and "Aragonese Naples," in The Renaissance: From the 1470s to the End of the 16th Century, ed. Iain Fenlon (Englewood Cliffs, NJ: Prentice Hall, 1989), pp. 156-73.

25. Atlas, "Aragonese Naples," pp. 161-62.

26. Prizer, pp. 159-60; see also the fuller discussions in Merkley and Merkley.

27. Lewis Lockwood, Music in Renaissance Ferrara 1400-1505: The Creation of a Musical Center in the Fifteenth Century (Cambridge, MA: Harvard University Press, 1984), pp. 149-54.

28. Chistopher A. Reynolds, Papal Patronage and the Music of St. Peter's, 1380-1513 (Berkeley: University of California Press, 1995), ch. 2 and table 5.

29. Palisca, p. 204.

30. On the music in the chapels of fifteenth-century Florence see Albert Seay, "The 15th-Century Cappella at Santa Maria del Fiore in Florence," Journal of the American Musicological Society 11 (1958): 45-55, and two articles by Frank A. D'Accone: "The Singers of San Giovanni in Florence during the $15^{\text {th }}$ Century," Journal of the American Musicological Society 14 (1961): 307-58, and "Some Neglected Composers in the Florentine Chapels, $c$. 1475-1525," Viator 1 (1970): 263-88.

31. Lorenzo de' Medici's role as patron is discussed in Frank A. D'Accone, "Lorenzo il Magnifico e la musica," in Piero Gargiulo, ed., La musica a Firenze al tempo di Lorenzo il Magnifico: Congresso internazionale di studi, Firenze, 15-17 giugno, 1992 (Florence: L. S. Olschki, 1993), pp. 219-48.

32. See above, note 18, regarding Ghiselin and Isaac. Alexander Agricola (c. 1445/46-1506) was born in Ghent and pursued his career in Italy, France and the Low Countries. He was appointed to the Florentine Cathedral in 1491; see his biography by Rob C. Wegman in Grove Music Online.

33. Savonarola's impact on music is studied by Patrick Macey in Bonfire Songs: Savonarola's Musical Legacy (Oxford: Clarendon Press, 1998). 
34. For details on the chapels, see Frank A. D'Accone, "The Musical Chapels at the Florentine Cathedral and Baptistry during the First Half of the 16th Century," Journal of the American Musicological Society 24.1 (1971): 1-50, esp. 1-23.

35. This point is made effectively in Iain Fenlon and James Haar, The Italian Madrigal in the Early Sixteenth Century: Sources and Interpretation (Cambridge: Cambridge University Press, 1988), pp. 39-40. D'Accone gives a comparable assessment of the chapels before the Medici restoration and then details the continued rebuilding up to Verdelot's arrival in "The Musical Chapels," pp. 13-17.

36. For a recent summary of his life and works, see Slim and La Via, "Verdelot, Philippe," in Grove Music Online. For a fuller account of the evidence of Verdelot's life before 1521, see Fenlon and Haar, The Italian Madrigal, pp. 37-39.

37. On Verdelot's life in Florence see D'Accone, “The Musical Chapels," pp. 17-19, and Fenlon and Haar, The Italian Madrigal, pp. 39, 41-46.

38. See, for example, the letter by Niccoló de Pictis to Giulio de' Medici recommending Verdelot to the Cardinal's service (Richard Sherr, "Verdelot in Florence, Coppini in Rome, and the Singer 'La Fiore'," Journal of the American Musicological Society 37 [1984]: 402-4). Verdelot is also mentioned by Antonfrancesco Doni in his Dialogo della musica (Venice, 1544) and I Marmi (Florence, 1552), which include much useful information about music and musicians of the time.

39. Fenlon and Haar, The Italian Madrigal, pp. 20-22, and pp. 22-37 on the manuscripts themselves.

40. Regarding Bembo's impact on the madrigal, see Dean T. Mace, "Pietro Bembo and the Literary Origins of the Italian Madrigal," Musical Quarterly 55.1 (1969): 65-86.

41. On Verdelot's pro-Republican sympathies, see Fenlon and Haar, The Italian Madrigal, pp. $42-45$.

42. Ibid., p. 22 et passim.

43. The literature on the genesis of the madrigal is substantial. The struggle to re-evaluate the musical sources is visible in the articles and accompanying discussions in James Haar, ed., Chanson \& Madrigal, 1480-1530: Studies in Comparison and Contrast: A Conference at Isham Memorial Library, September 13-14, 1961 (Cambridge, MA: Harvard University Press, 1964). For a coherent and convincing study, see Fenlon and Haar, The Italian Madrigal. 